\title{
Compost and Compost Tea Fertilization Effects on Soil and Artichoke Mineral Nutrition in Organic Farming
}

\author{
Karima Kouki Khalfallah ${ }^{\dagger}$ NejibTurki ${ }^{* *}$, Mariem Rébaï ${ }^{\dagger}$ et Ismaïl Ghazel ${ }^{\ddagger}$ \\ †(INAT): National Agronomic Institute of Tunis-Tunisia, 43 Avenue Charles Nicolle Tunis - Tunisia \\ $\neq($ SAM): Station d'Appui de Manouba, Groupement Interprofessionnel des Légumes - Tunisia
}

Accepted 18 Dec 2015, Available online 20 Dec 2015, Vol.5, No.6 (Dec 2015)

\begin{abstract}
This study aims to improve fertilization management of artichoke in organic farming. Four fertilization program treatments based on compost and compost tea have been experienced: Control Treatment (T0): 100\% compost needs are made in solid form before planting (BP);Treatment 1 (T1 ): 50\% compost needs are made in solid form BP , 25\% are made in solid form at 22 weeks after planting (WAP) and 25\% are applied as compost tea sprayed on the leaves weekly for 26 weeks from 12 WAP, Treatment 2 (T2): 50\% compost needs are made in solid form BP and 50\% in the form of compost tea applied by fertigation weekly for 26 weeks from 12 WAP and Treatment 3 (T3 ): $50 \%$ compost needs are made in solid form BP ,25\% in the form of compost tea applied as a foliar spray and 25\% in the form of compost tea applied by fertigation. T3 provides better plants supplied with nitrogen, higher dry matter content and higher phosphorus potassium and calcium levels that reached 8.8\%, 11\% and 16\% respectively for P, K and Ntot compared to control. Compost application once before planting (T0) limits plant nutrient supplies during crop season. Splitting compost is more effective for nutrient supplies than its full input before planting. Combining compost tea foliar spray with fertigation allows to have better nutrient provides than the use of every single application method.
\end{abstract}

Keywords: Organic farming, compost, compost tea, foliar spray, fertigation, mineral nutrition.

\section{Introduction}

Organic agriculture relies on ecosystem management and sustainable manner autonomously (Rodet, 1978; De Silguy, 1997). The organic production system is based on production standards which aims to ensure Social, environmental and economic sustainable optimal conditions. It is bordered by various laws and certification programs that are the subject of checks by certifying bodies accredited by the states concerned (FAO, 1999). Fertilization in organic agriculture aims to maintain and develop the natural soil fertility in the long term by encouraging the recycling of organic matter and compost production (Guet, 2003). Organic matter stimulates the activity of microbial populations, which causes enzymatic degradation of substances incorporated into the soil. Organic compounds more simple are then formed while simultaneously are elaborated humic molecules (De Silguy, 1997). The C / $\mathrm{N}$ ratio is one of the most critical parameters for the rate of degradation of organic matter and therefore more or less rapid release minerals (Pouech, 2006). In general, a lack of nitrogen involves a slow degradation and excessive nitrogen causes severe loss in nitrogen

*Corresponding author: NejibTurki
(Godden, 1995). The composted organic matter or simply compost is the result of aerobic decomposition of fresh organic material of vegetable and / or animal with the microorganisms activity (Godden, 1995). The compost is subject to regulatory requirements to ensure that it does not pose health and toxicological problems during use, and several countries have adopted specific standards. Compost is generally used in solid form as an amendment during soil preparation (CTAB, 2009). Nevertheless, in organic farming, limiting the input of compost to the soil preparation phase is likely to be unsatisfactory for crops during their cycle, especially when their nutrient requirements are highest.

This is particularly true for demanding species such as artichoke (Odet et al, 1989; Bratsch, 2009) that develops a significant vegetative biomass and whose crop cycle extends over 7 months. Several authors have confirmed the positive effect of compost based fertilization on vegetable crops parameters such as strawberries, carrots, artichoke or pepper (Masmoudi Charfi et al, 2001; Kouki Khalfallah and Bouhaouech, 2009; Tarchoun and Ben Khedher, 2010; Turki and kouki khalfallah, 2014). Compost contributes to the enrichment and maintenance of soil fertility, it creates 
optimal conditions for plants growth through mineralization and made available for plant nutrients (Davet, 1996). The soil cation exchange capacity is significantly increased, especially in light soils with low adsorption capacity (Calvet, 2003). Significant increases in organic carbon and total nitrogen are also observed in the amended soils especially in the topsoil (Zwart, 2001). The nutrient concentration released into the soil varies widely depending on the type used compost. In the case of compost allowed in organic farming, and prepared generally based manure and green waste, nutrient levels can vary within fairly wide limits, some for $\mathrm{P}, \mathrm{K}$ and $\mathrm{Mg}$ were identified by Weinfurtner (2001). Composts role as a crop fertilizer is also increasingly mentioned either by foliage spray, or by injection into the irrigation water (Merrill and McKeon, 1998; El Naggar , 2002; Nikolic, 2003). The compost extract is most often used as a soil or foliage microbiological inoculants as it contains millions of bacteria, fungi and other microorganisms that help keep plants free of diseases (Guet, 2003). It also reduces the toxicity potential of the organic acids by plants and toxic metabolites (Quarles, 2001) .

This work aims to improve the organic fertilization of the artichoke. It offers the opportunity to test split of compost at the rate of $50 \%$ before planting and make the rest of the needs during the crop cycle in different forms.

\section{Materials and Methods}

\subsection{Experimental site}

The experiment was conducted in the Manouba Tunisia Support Station (SAM) which is under the Inter-professional Groupement of Vegetables (GIL). The SAM is located $3 \mathrm{~km}$ on the road of Tunis - Jedaida in the Manouba Governorate in northern Tunisia: latitude $36^{\circ} 48$ 'north; longitude $10^{\circ} 03$ 'East, altitude $469 \mathrm{~m}$. The climate stage of the region of Manouba is the upper semi-arid. Rainfall is irregular with an annual average of $450 \mathrm{~mm}$.

\section{2 plant material}

"Violet d'Hyeres" is the artichoke Variety object of this test, which is one of the most cultivated in Tunisia and most appreciated for its profitability. It is generally classified as semi-late in comparison with other varieties.

\subsection{Compost based fertilization}

The compost used in this study was prepared by the Technical Center of Organic Agriculture (CTAB) using a mixture based on cattle manure (65\%), poultry manure (20\%), straw (10\%) and sheep manure (5\%). The duration of composting was 7 months. The total quantity of compost made to the culture of artichoke was $9 \mathrm{t} / \mathrm{ha}$. The compost needs assessment was based on the standard loading animals for a farm practicing organic farming (Jort, 2005) which states that the annual nitrogen input may not exceed $170 \mathrm{~kg} / \mathrm{ha}$ and taking into account the analysis of the nitrogen content of the compost which is $2 \%$ of dry matter, and its dry matter content is $94 \%$,

\subsection{Compost tea extraction}

The compost tea was prepared at the rate of once a week for 26 weeks using the method developed by (Weltzien, 1992) described and performed later by (Znaidi, 2002). For the foliar spray, the extraction was performed in accordance with the proportion of 1 volume compost for 5 volumes of water, while for fertigation, extraction was made in a larger volume of water in accordance with an extraction rate of $8 \%$ in order to have an easier time in homogeneous distribution of the compost tea on the whole plot concerned.

\subsection{Experimental device}

Four compost based fertilization treatments have been experienced in this trial:

Control Treatment (T0): 100\% compost needs are made in solid form before planting;

Treatment 1 (T1 ): 50\% compost needs are made in solid form before planting , 25\% are made in solid form at 22 weeks after planting (early stem elongation) and $25 \%$ are applied as compost tea sprayed on the leaves weekly for 26 weeks from 12 weeks after planting (5-6 leaves stage).

Treatment 2 (T2): 50\% compost needs are made in solid form before planting and $50 \%$ in the form of compost tea applied by fertigation weekly for 26 weeks from 12 weeks after planting (5-6 leaves stage). Treatment 3 (T3 ): 50\% compost needs are made in solid form before planting , $25 \%$ in the form of compost tea applied as a foliar spray and $25 \%$ in the form of compost tea applied by fertigation weekly for 26 weeks from the $12^{\text {th }}$ week after planting (5-6 leaves stage).

The experimental design is used in a randomized complete block with three replicates. In each block, the 4 treatments are randomly assigned to each represented by a basic plot with an area of $109.2 \mathrm{~m}^{2}$ The blocks are made in the direction of planting lines and treatments distributed laterally at 2 lines per treatment.

\subsection{Compost tea distribution program}

A weekly distribution program of compost tea was prepared for T1, T2 and T3 treatments in the amounts provided for each treatment (Table 1). For this, the amount of the additional solid compost fraction on each treatment was divided in 26 equal portions, which were extracted in water and is completely distributed 
weekly by foliar spray for $\mathrm{T} 1$, either entirely by injection in the irrigation system for T2, or by using both means for parallel application in T3. Compost tea based fertilization started at the $12^{\text {th }}$ week and was stopped at the $38^{\text {th }}$ week after planting.

Table 1: Compost inputs provided for each treatment (t/ha)

\begin{tabular}{|c|c|c|c|c|}
\hline Inpurs & & & & \\
\hline & To & $\mathrm{Tn}$ & $\mathrm{T} 2$ & T3 \\
\hline $\begin{array}{l}\text { Solid compost applied before } \\
\text { planting }\end{array}$ & 9 & 4.5 & 4,5 & 4,5 \\
\hline $\begin{array}{l}\text { Solid compost applied } 22 \text { weeks } \\
\text { after planting }\end{array}$ & & & & \\
\hline & & & & \\
\hline Compost used in the exraction of & 0 & 2.25 & 0 & 225 \\
\hline Compost tea used for foliar spray & & & & \\
\hline $\begin{array}{l}\text { Compost used in the exraction of } \\
\text { Compost tea used for fertigation }\end{array}$ & 0 & 0 & 4,5 & 2,25 \\
\hline Total $(\mathrm{T} / \mathrm{Ha})$ & 9 & 9 & 9 & 9 \\
\hline
\end{tabular}

\subsection{Parameters measured}

\subsubsection{Soil analysis}

Soil in $0-40 \mathrm{~cm}$ soil layer was analyzed by taking samples, first at the time of preparation of the soil before adding organic matter, and then every 2 months from November to May in order to follow the evolution of different soil parameters. Soil texture was determined by sieve column and a Robinson-Kohn pipette (Pauwels et al., 1992), Organic matter (OM) was determined by Walkley and Black method (Pauwels et al., 1992), pH was measured by Hach sension $3 \mathrm{pH}$-meter $(0,01$ precision), total limestone was determined by the NF ISO 10693 standard method (Baize, 2000) and the active CaCO3 by the Afnor X 31106 method (Baize et Girard, 2009), Electric Conductivity (EC) was measured by Tacussel Conductimeter, total nitrogen (Ntot) was determined by Kjeldahl method, available soil phosphorus was determined by Olsen method and exchangeable potassium, calcium and sodium was determined by Sherwood flame photometer (Pauwels et al., 1992).

\subsubsection{Foliar diagnosis}

To be aware of the nutritional status of plants, foliar diagnosis was made, dry matter then Ntot, phosphorus, potassium, calcium and sodium was determined.

\subsubsection{Compost analysis}

Compost analysis concerned the physical aspects: the bulk density, moisture, content of dry matter and organic matter and chemical aspects: $\mathrm{pH}$, electrical conductivity (EC), and mineral content of Ntot, P, K, Ca, $\mathrm{Na}$ by methods previously described (Pauwels et al., 1992).

\subsection{Statistical Analysis}

Analysis was performed using the SPSS program (SPSS $20.0)$, by analysis of variance $(p<0.05)$. In case of significance for interactions or between levels of the isolated factors, the Duncan test was applied $(\mathrm{p}<0.05)$.

\section{Results and Discussion}

\subsection{Compost analysis}

The compost used in this experiment (Table 2) was provided by the Organic Agriculture Technic Center (CTAB) has a very low water content. Its $\mathrm{pH}$ is close to neutrality, but its EC is relatively high. This is a rather well done compost, which would have a medium decomposition rate according to the assessments of Martin-Lafleche cited by Odet et al. (1989). Comparing it to an average cattle manure described by Odet et al. (1989), it appears almost as rich in nitrogen and phosphorus, much more concentrated in calcium, but less rich in potassium (Table 3).

\subsection{Soil analysis results}

\subsubsection{Initial state before plantation}

Soil analysis results (Table 4) show that its texture is silty clay and sandy according to the GEPPA triangle texture. The soil is considered to be alkaline with a $\mathrm{pH}$ of 8.4, salinity is low with EC of $0.62 \mathrm{dS} . \mathrm{m}^{-1}$, with a slight risk of chlorosis active limestone content of $7 \%$, and low OM content $1.45 \%$. Nutrient appreciation contents classifies it as low provided in nitrogen and phosphorus and rich in potassium considering the standard described by Odet et al. (1989).

\section{$3.2 .2 \mathrm{pH}$}

The monitoring of soil $\mathrm{pH}$ from its initial state until the end of the culture (Fig 1) shows the overall decrease in $\mathrm{pH}$ in all treatments. This decline is much sharper for $\mathrm{T} 2$ compared to treatment $\mathrm{T} 1$ and $\mathrm{T} 3$ and more compared to $\mathrm{T} 0$.

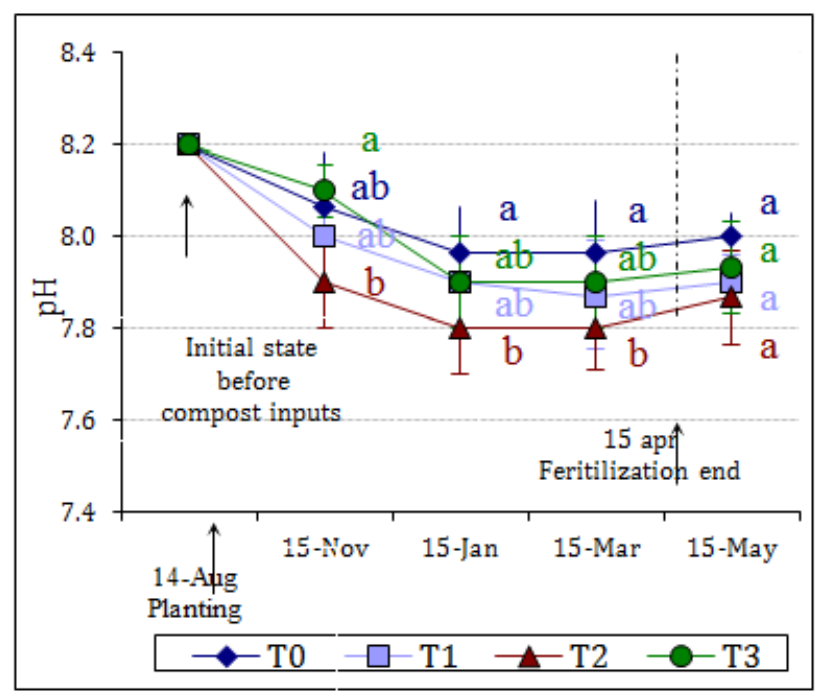

NB : The values for the same date and assigned by the same index are not significantly different at $5 \%$ risk of error

Fig 1: Soil pH evolution depending on fertilization treatments applied 


\subsubsection{Electrical Conductivity (EC)}

Monitoring of soil EC (Fig 2) shows a significant decrease in this parameter from the initial state (before compost inputs) and the first check 24 days after the start of fertigation (November 15) for all treatments. Then soil EC has remained fairly stable and no significant differences were observed between treatments.

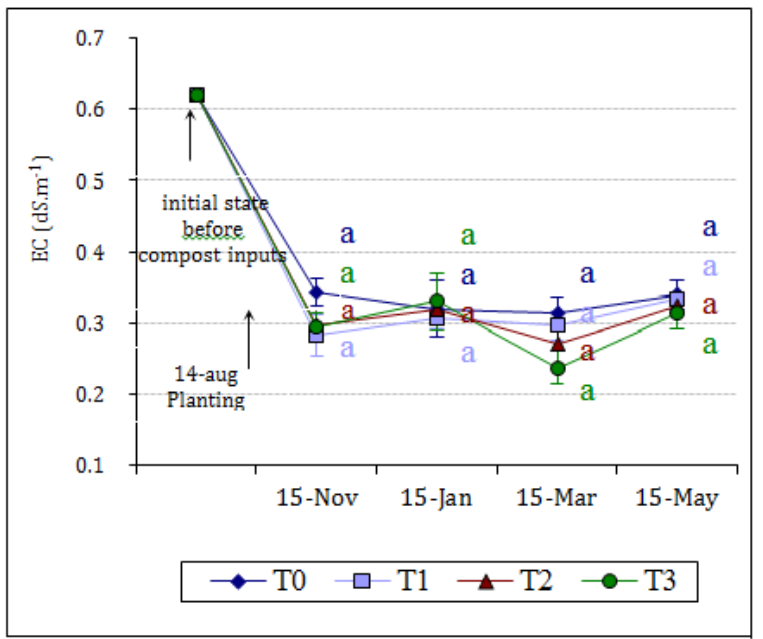

NB : The values for the same date and assigned by the same index are not significantly different at $5 \%$ risk of error

Fig 2 Soil EC evolution depending on fertilization treatments applied

\subsubsection{Soil OM content}

The evaluation of the soil OM content (Fig 3) allows to note a significant increase from the initial state (before compost inputs) and the first control (15 November) made 13 weeks after planting. Nevertheless, the increase was more pronounced in the control (T0) which received $100 \%$ of compost needs before planting, while the other treatments (T1, T2 and T3) had received only $50 \%$.

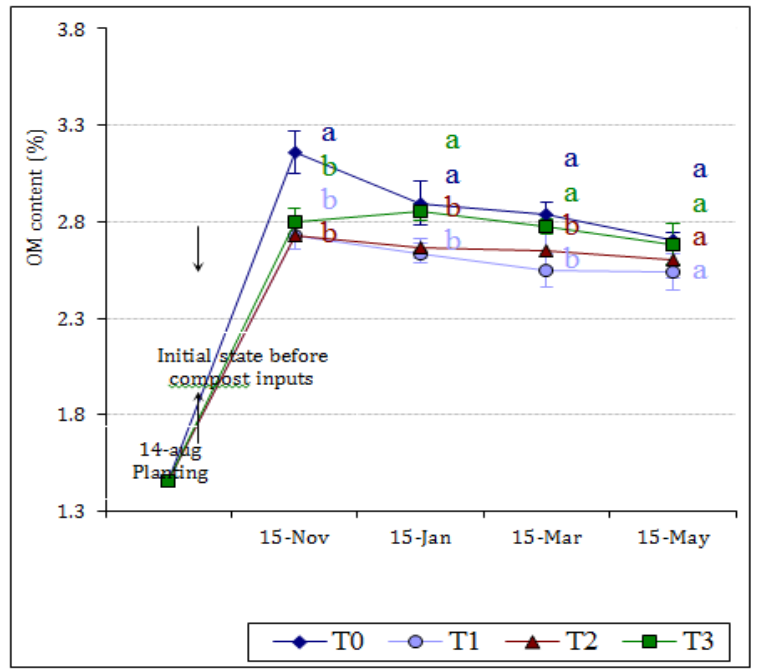

NB: The values for the same date and assigned by the same index are not significantly different at $5 \%$ risk of error

Fig 3: Soil OM content evolution depending on fertilization treatments applied
Two months after the first inspection, the OM content decreases significantly for $\mathrm{T} 0$, as well as for $\mathrm{T} 1$ and $\mathrm{T} 2$, but it remains higher in the first. The decrease continues as the crop cycle advances. For the T3 treatment, OM content, which was similar to that of T1 and $\mathrm{T} 2$ at the first control (15 November), continued to be in a slight increase in the second control after two months; and was closer to T0. No more significant difference was then monitored between $\mathrm{T} 0$ and $\mathrm{T} 3$ since the lowering of their OM content continued with similar rhythms.

Table 2: Compost analysis results

\begin{tabular}{|c|c|}
\hline Parameters & Results \\
\hline \multicolumn{2}{|c|}{ Physical properties } \\
\hline Humidity (\%) & 6 \\
\hline Bulk density & 0,7 \\
\hline \multicolumn{2}{|c|}{ Chemical properties } \\
\hline $\mathrm{pH}$ & 7,5 \\
\hline $\mathrm{EC}(\mathrm{dS} / \mathrm{m})$ & 2,74 \\
\hline Carbon (g/kg) & 330,76 \\
\hline $\mathrm{OM}(\mathrm{g} / \mathrm{kg})$ & 580 \\
\hline Ntot $(\mathrm{g} / \mathrm{kg})$ & 18,8 \\
\hline $\mathrm{C} / \mathrm{N}$ & 18 \\
\hline Phosphorus (g/kg) & 5,8 \\
\hline Potassium (g/ kg) & 8,8 \\
\hline Calcium (g / kg) & 43,4 \\
\hline Sodium $(\mathrm{g} / \mathrm{kg})$ & 4,8 \\
\hline
\end{tabular}

Table 3: Comparison between the compost used and cattle manure compost described by Odet et al. (1989)

\begin{tabular}{|c|c|c|c|c|}
\hline & \multicolumn{4}{|c|}{ Concentrations (g/ kg MS) } \\
\hline & $\mathrm{N}$ & $\mathrm{P}_{2} \mathrm{O}_{5}$ & $\mathrm{~K}_{2} \mathrm{O}$ & $\mathrm{CaO}$ \\
\hline Compost used(1) & 18,8 & 13,3 & 10,6 & 60,6 \\
\hline Cattle manure compost (2) & 20 & 11,1 & 22,2 & 35,5 \\
\hline Ratio: $(1) /(2)$ & 0,94 & 1,20 & 0,48 & 1,72 \\
\hline
\end{tabular}

\subsubsection{Ntot}

Soil Ntot evolution (Fig 4) was very similar to that of $\mathrm{OM}$ for all treatments except for the last soil sampling conducted on May 15 Indeed, where Ntot content in the top 40 centimeters soil, fell sharply the control T0 at the lowest value compared to other treatments.

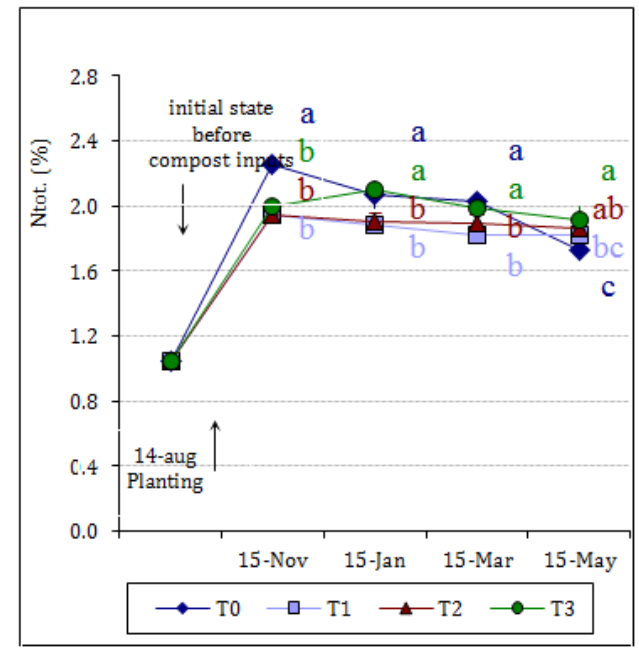

NB: The values for the same date and assigned by the same index are not significantly different at $5 \%$ risk of error

Fig 4: Soil Ntot content evolution depending on fertilization treatments applied 


\subsubsection{Available Phosphorus}

The available phosphorus content (Fig 5) shows a significant increase from the initial state (before compost inputs) and the first control (15 November) made 13 weeks after planting. Nevertheless, the increase was more pronounced in the control (T0) which received $100 \%$ of compost needs before planting, while the other treatments (T1, T2 and T3) had received 50\%. The phosphorus content then decreased in the control significantly, which has reduced the value to a very low level $(12 \mathrm{ppm})$ to the crop cycle end. Lowering the available phosphorus content was shifted further for $\mathrm{T} 1$, then for $\mathrm{T} 2$ and $\mathrm{T} 3$, since his values began to fall respectively from January 15 for the first and March 15 for the last two.

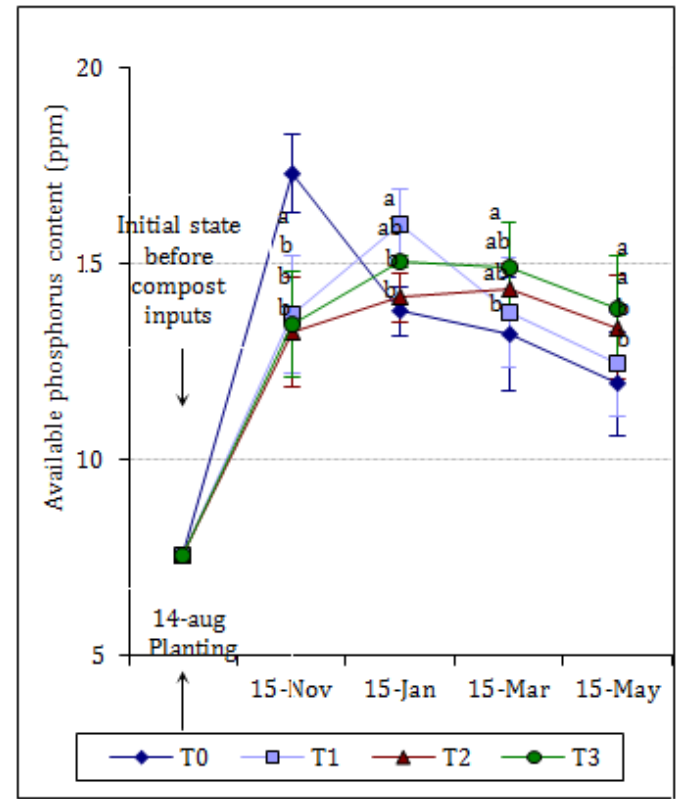

NB: The values for the same date and assigned by the same index are not significantly different at $5 \%$ risk of error

Fig 5: Available Soil phosphorus content evolution depending on fertilization treatments applied

Table 4: Soil Composition before plantation

\begin{tabular}{|c|c|}
\hline Parameters & Results \\
\hline \multicolumn{2}{|c|}{ Texture } \\
\hline Clay (\%) & 28,3 \\
\hline Fine silt (\%) & 31,3 \\
\hline Coarse silt (\%) & 16,3 \\
\hline Sand (\%) & 24,1 \\
\hline \multicolumn{2}{|c|}{ Chemical properties } \\
\hline $\mathrm{pH}$ & 8,4 \\
\hline $\mathrm{EC}\left(\mathrm{dS} \cdot \mathrm{m}^{-1}\right)$ & 0,6 \\
\hline Total limestone (\%) & 14,6 \\
\hline Active limestone (\%) & 7 \\
\hline $\mathrm{OM}(\%)$ & 1,4 \\
\hline Organic Carbon(\%) & 0,8 \\
\hline Ntot $(\%)$ & 1,04 \\
\hline Phosphorus (ppm) & 7,6 \\
\hline Potassium (ppm) & 325 \\
\hline Calcium (ppm) & 5600 \\
\hline Sodium (ppm) & 345 \\
\hline
\end{tabular}

\subsubsection{Exchangeable Potassium}

Monitoring the exchangeable potassium content (Fig 6) shows an increase to the first control (15 November) made 13 weeks after planting compared to the soil initial state before compost inputs.

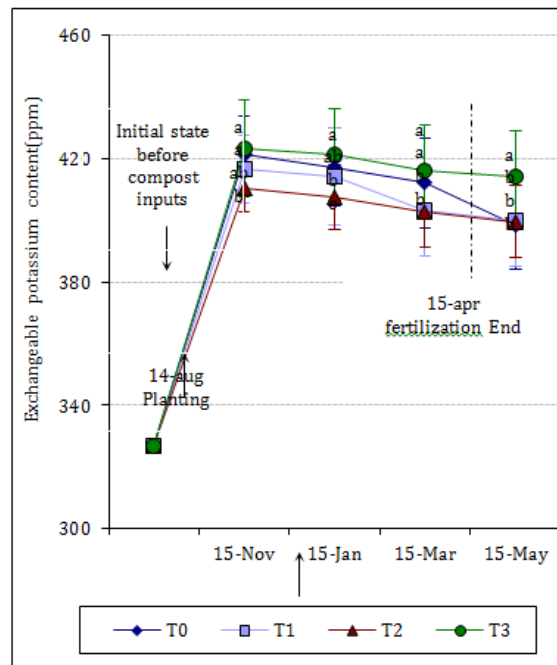

NB: The values for the same date and assigned by the same index are not significantly different at $5 \%$ risk of error

Fig 6: Exchangeable Soil potassium content evolution depending on fertilization treatments applied

Nevertheless, the differences between treatments were not very pronounced, although significant. Even T0 values are not very high compared to those in other treatments. The exchangeable potassium content has, however, decreased over time in the crop cycle for all treatments, but more attenuated in T3 compared to T0, $\mathrm{T} 1$ and $\mathrm{T} 2$

\subsubsection{Exchangeable Calcium}

The soil exchangeable content of calcium (Fig 7) increased slightly between initial state and the start of the application of compost-based fertilizer programs, for all treatments.

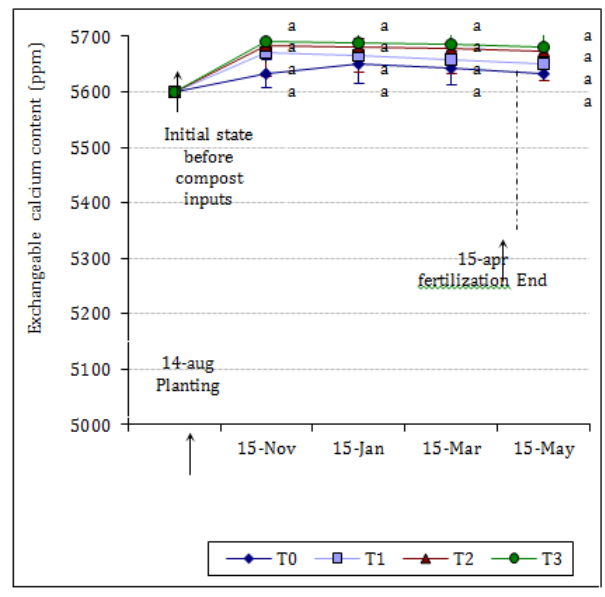

NB: The values for the same date and assigned by the same index are not significantly different at $5 \%$ risk of error

Fig 7: Exchangeable Soil calcium content evolution depending on fertilization treatments applied 
Nevertheless, values have remained stable and no significant differences were observed between treatments.

\subsubsection{Exchangeable Sodium}

The exchangeable soil sodium content (Fig 8) shows a significant increase compared to the initial state at the first control carried out on November 15, or 13 weeks after planting. This increase in the sodium content was greater in the T0 which received $100 \%$ of compost before planting needs, while the other treatments (T1, $\mathrm{T} 2$ and $\mathrm{T} 3$ ) had not then received 50\%. The exchangeable sodium content of the soil has then gradually decreased in all treatments, but more accelerated in the control, followed by T1, which received a second supply of compost $(25 \%$ of requirements) in solid form in January and finally by $\mathrm{T} 2$ and $\mathrm{T} 3$, which have received more solid compost at no time during cultivation, which after fertilization was made compost extracts applied to the base of leaves and / or with water irrigation.

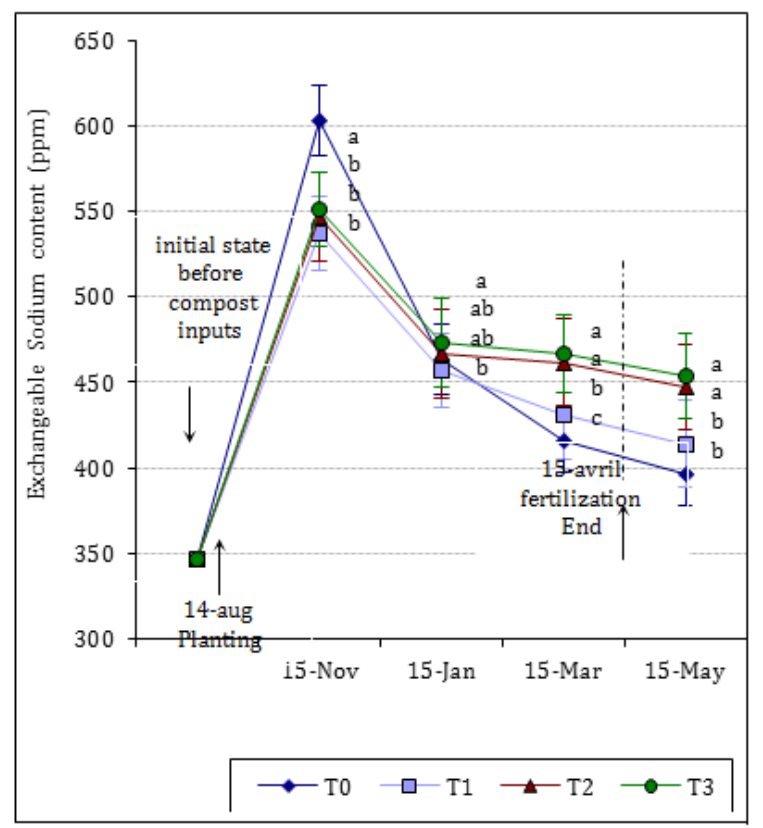

NB: The values for the same date and assigned by the same index are not significantly different at 5\% risk of error

Fig 8: Exchangeable Soil Sodium content evolution depending on fertilization treatments applied

\subsection{Foliar Diagnosis}

The artichoke leaves analysis (Table 5) shows that the dry matter content, as well as their mineral composition varied significantly with fertilization programs applied. The dry matter content increased significantly compared to control, but more pronounced in T3 compared to T2 and T1. Nitrogen has varied substantially in the same direction as the dry matter; phosphorus increased compared to the control, but remained similar in $\mathrm{T} 1, \mathrm{~T} 2$ and $\mathrm{T} 3$; potassium and calcium increased compared to the control, but more significantly at T1 and T3 compared with T2; and finally the sodium increased significantly compared to control T0, but in the same way for T1, T2 and T3. T3 showed the best improvements in diet of the plant compared to the control. Although this improvement did not exceed $2 \%$ for $\mathrm{Na}$ and $3 \%$ in $\mathrm{DM}$ and $\mathrm{Ca}$, it reached $8.8 \%, 11 \%$ and $16 \%$ respectively for $\mathrm{P}, \mathrm{K}$ and Ntot.

Table 5: Artichoke leaves dry matter (DM) Contents relative to the fresh material (\%FM) and mineral elements based on dry matter (\% DM) taken March 17

\begin{tabular}{|c|c|c|c|c|}
\hline Analysis & T0 & $\mathrm{T} 1$ & $\mathrm{~T} 2$ & T3 \\
\hline $\mathrm{DM}$ & $\begin{array}{c}12,500 \pm \\
0,266^{c}\end{array}$ & $\begin{array}{c}12,812 \pm \\
0,122^{\mathrm{b}}\end{array}$ & $\begin{array}{c}12,864 \pm \\
0,151^{\mathrm{b}}\end{array}$ & $\begin{array}{c}12,910 \pm \\
0,271^{\mathrm{a}}\end{array}$ \\
\hline $\mathrm{N}$ tot. & $\begin{array}{r}2,370 \pm \\
0,052 \mathrm{c} \\
\end{array}$ & $\begin{array}{l}2,500 \pm \\
0,051 \mathrm{~b}\end{array}$ & $\begin{array}{l}2,530 \pm \\
0,053 \text { b }\end{array}$ & $\begin{array}{l}2,760 \pm \\
0,051 \text { a }\end{array}$ \\
\hline Phosphorus & $\begin{array}{r}0,170 \pm \\
0,012 \mathbf{b} \\
\end{array}$ & $\begin{array}{l}0,186 \pm \\
0,022 \text { a } \\
\end{array}$ & $\begin{array}{l}0,182 \pm \\
0,014 \text { ab }\end{array}$ & $\begin{array}{l}0,187 \pm \\
0,033 \text { a }\end{array}$ \\
\hline Potassium & $\begin{array}{r}0,820 \pm \\
0,003 \text { c }\end{array}$ & $\begin{array}{l}0,907 \pm \\
0,004 \text { a }\end{array}$ & $\begin{array}{l}0,893 \pm \\
0,004 \text { b }\end{array}$ & $\begin{array}{l}0,911 \pm \\
0,004^{\text {a }}\end{array}$ \\
\hline Calcium & $\begin{array}{r}0,198 \pm \\
0,001 \mathrm{c} \\
\end{array}$ & $\begin{array}{l}0,205 \pm \\
0,002 \text { a }\end{array}$ & $\begin{array}{c}0,201 \pm \\
0,002 \mathrm{~b} \\
\end{array}$ & $\begin{array}{l}0,205 \pm \\
0,002 \text { a }\end{array}$ \\
\hline Sodium & $\begin{array}{r}0,310 \pm \\
0,002 \text { b }\end{array}$ & $\begin{array}{l}0,316 \pm \\
0,001 \text { a }\end{array}$ & $\begin{array}{c}0,316 \pm \\
0,002 \text { a }\end{array}$ & $\begin{array}{l}0,317 \pm \\
0,001 \text { a }\end{array}$ \\
\hline
\end{tabular}

\section{Discussion}

Monitoring of chemical soil parameters and a foliar diagnosis was carried out on March,17 to understand the origin of the observed differences between treatments in terms of growth, production and product quality. For chemical soil parameters monitoring, it was found a general decrease in $\mathrm{pH}$ which is more pronounced under the T2 treatment compared to other treatments (Fig 1). This could be explained by the contribution of $50 \%$ of compost needs through fertigation in $\mathrm{T} 2$ by compost tea, while in other treatments only $25 \%$ of the needs were applied by compost tea (as in T3). The soil pH lowering due to the use of compost tea applied to the soil has already been observed by Nikolic (2003). For nitrogen nutrition, plants submitted to T3 treatment were significantly better fed; they also presented the highest dry matter content (Table 5). The supply of compost by the combined foliar fertigation (T3) seems to give better results than the single foliar (T1) or the only fertigation (T2). Indeed, the supply of nitrogen through the leaves is more effective than its soil application (Chaudhui et al. 1975 cited by Skiredj, 2007). The phosphorus strongly decreased during crop cycle in the soil of control treatment (Fig 5). It has simultaneously been found with lower levels in leaves than in other treatments. The release of phosphorus by organic matter seems to occur at a slower pace than its absorption by the roots in the control for which was used only the solid form made before planting. This can be a disadvantage for the artichoke which is a perennial plant accumulating reserves in the roots and strain (Odet et al., 1989; Bratsch 2009). Fractionation of compost has been favorable to the absorption of 
phosphorus in all the treatments T1, T2 and T3. These results are reminiscent of Chaudhui et al. (1975) cited by Skiredj (2007) who found greater efficiency in foliar application of phosphorus compared to soil application especially in poor soil. Potassium soil content remained highest in T3 throughout the crop cycle (Fig 6 ), but that in the leaves was raised both in T3 than in T1 (Table 5) while in these two treatments, the compost tea was applied to the foliage, which seems to be advantageous for potassium artichoke plants absorption. The same phenomenon has been observed for calcium in the leaves, the content was highest in T3 and $\mathrm{T} 1$. The effectiveness of foliar fertilization based on potassium and calcium (Maltais, 2006) seems to be confirmed, which reflects the high mobility of these elements, giving them a rapid distribution through the plant. Soil sodium content has risen sharply compared to the initial state following the soil solid compost incorporation before planting $(100 \%$ of the requirements in $50 \%$ of $\mathrm{T} 0$ and $\mathrm{T} 1$ needs, $\mathrm{T} 2$ and $\mathrm{T} 3$ ). This content has decreased remarkably during cultivation probably due to leaching in all treatments (Fig 8). Nevertheless, it remained relatively high in T2 and T3 treatments in which the compost tea was applied using fertigation throughout the crop cycle. Leaf analysis revealed no significant difference between treatments $\mathrm{T} 1 \mathrm{~T} 2$ and $\mathrm{T} 3$, the contents were nevertheless slightly higher than that of T0. Combining compost tea foliar spray with fertigation allows to have better results than the use of every single application method. Soil mineral status and foliar diagnosis explains agronomic results of this experiment and previously published (Kouki khalfallah et al., 2014) who showed that the best performance (17.4 tons / ha), precocity (3.5 tons / ha harvested before March 16) and quality of the heads (15 tons / ha were classified between the categories Extra and I) was obtained by splitting compost application and combining fertigation and foliar spray compost tea for artichoke.

\section{Conclusion}

The plants nutritional status monitoring through foliar diagnosis confirmed that the plants subjected to T3 were better supplied with nitrogen, had a higher solids content and had higher phosphorus potassium and calcium levels. The treatments T1 and T2 were very close to their nitrogen content and dry matter content, but $\mathrm{T} 1$ has been best for its phosphorus, potassium and calcium. The leaves fertilization by compost tea seems to allow a slightly better mineral nutrition than compost tea fertigation, but combination of fertigation and foliar spray remains the best alternative. Compost application once before planting (T0), which is the most currently used in organic farming method has clearly shown its limits. The decomposition of organic matter was relatively slow, which provide the plant reduced amounts of phosphorus, potassium and calcium compared to other treatments and especially T3. This work has provided evidence that splitting compost is more effective than its incorporation in full in the soil before planting. Combining compost tea foliar spray with fertigation allows to have better results than the use of every single application method. The results of this work could be further clarified in subsequent research work especially for soil compost ratio applied before planting and distribution of compost tea through foliar spray and fertigation.

\section{Acknowledgements}

The development of this work has been achieved with the valuable contribution of the staff of the support station of Manouba (SAM).

\section{Conflict of interest}

The authors declare that there is no conflict of interest.

\section{References}

Baize D., (2000), Guide des analyses en pédologie. 2éme Edition. Edition INRA, 257

Baize D., Girard M., (2009), Référentiel pédologique 2008 Edition Quae , 405.

Bratsch A., (2009), Specialty Crop Profile, Globe Artichoke. Virginia Polytechnic Institute and State University. Publication 438-108. Present in the link: http://pubs.ext.vt.edu/438/438-108/438-108.pdf.

Calvet R., (2003), Le sol: propriétés et fonctions. Constitution, structure, phénomènes aux interfaces. France Agricole Editions : 455

CTAB, (2009), Guide de bonne pratique pour la conduite biologique de l'artichaut. ctab: 45 .

Davet P., (1996), Vie microbienne du sol et production végétale. Édition INRA. 383.

De silguy C., (1997), L'agriculture biologique : des techniques efficaces et non polluantes. Edition PATINO : 186.

El Naggar A. H., (2002), Effects of using water extracts from compost and organic materials on soil fertility and plant nutrition. Master of science in agriculture science. Department of organic farming. IAMB. ITALY: 109.

Fuchs J. G., (2009), Fertilité et pathogènes telluriques: effets du compost. Journées techniques fruits et légumes biologiques décembre 2009. Present in the link: http://www.biophyt.ch/documents/2009_Paris_w_f.pdf.

Godden B., (1995), Techniques et aspect du compostage dans une ferme biologique. Revue de l'Ecologie, No $13: 37$.

Guet G., (1993), Agriculture biologique méditerranéenne. Guide pratique à usage professionnel. France agricole éditions: 520 .

Guet G., (2003), Mémento d'agriculture biologique: Guide pratique à usage professionnel. France agricole éditions 416.

Kouki Khalfallah. K., Bouhaouach H., (2009), Valorisation du compost oasien en cultures maraîchères dans l'oasis de Chénini Gabès. Revue de l'INAT, Vol. 24 nº 2009.

Maltais A. M., (2006), Facteurs et conditions favorables à l'efficacité de la fertilisation foliaire des cultures maraîchères du Québec. Revue de littérature. Present in the link: http:// www.agrireseau. qc.ca/ horticulturepepiniere/ documents/ fertilisation foliaire_AM.pdf.

Merrill R., McKeon J., (1998), Organic teas from compost and manures in Organic Farming Research Foundation Project Report. Present in the link: http://www. 
scribd.com/doc/35310671/Organic-Teas-from-Compostsand-Manures.

Nikolic J., (2003), Study of compost water extract application through fertigation system in organic farming. Thesis Mediterranean Agronomic Institute of Bari. Present in the link: http://orgprints.org/6661/1/JovanNikolic03.pdf.

Odet J., Musard M., Wacquant C., (1989)., Mémento fertilisation des cultures légumières. Edition Ctifl : 398.

Pauwels J., Van Ranst E., Verloo M., Mvondize A., (1992), Manuel de laboratoire de pédologie. Edition AGCD : 265.

Peigné J., Girardin P., (2001), Compostage et Environnement. Revu Alter Agri $\mathrm{n}^{\circ} 27$ septembre/octobre 2001. Present in the link: http:// www.itab.asso .fr/downloads/ AlterAgri/AA49 pdf.

Pouech P., (2006), La valeur agronomique des composts. Synthèse bibliographique. Present in the link: http://www.apesa.fr/documentsapesa?view=document\&id $=28$.

Quarles W., (2001), Compost tea for organic farming and gardening. The IPM practioner, vol 23, $\mathrm{n}^{\circ}$ 9: 1-8.

Ragot M., (2001), Conversion à l'agriculture biologique: le cas de la production laitière. Educagri Editions : 355.

Rodet G., (1978), L'agriculture biologique. Ed camugli Lyon : 167.

Skiredj A., (2007), Fertilisation de la tomate industrielle, principaux résultats de la bibliographie, principaux axes de recherche. Present in the link: http://www.legume-fruitmaroc.com/axes-recherche-tomate-industrielle.pdf.
Skiredj A., et Elattir H., (2003), Fiches techniques VII : l'artichaut, le cardon, le mais doux, l'aspérge, le poireau. In transfert de technologie en agriculture. Numéro 102 Mars 2003. Present in the link: http://www. vulgarisation.net/102.pdf.

Tarchoun N., Ben Khedher M., (2010), Assessment of organic composts on growth and production of artichoke. International Journal of Vegetable Science, Volume 16, Issue 2 April 2010 : 191-198 (Abst).

Weinfurtner K., (2001), Plant Nutrition and Productivity - Is Compost a Competitive Fertiliser? In applying compost benefits and needs. Seminar proceedings Brussels, 22-23 November 2001. Present in the link: http://ec.europa.eu/ environment/waste/pdf_comments/040119_proceedings. pdf.

Weltzien H. C., (1989), Some effects of composted organic materials on plant health. Agric. Ecosystems Environ n ${ }^{\circ} 27$ : 439-446.

Znaidi I. A., (2002), Etude et évaluation du compostage de différents types de matières organiques et des effets des jus de composts biologiques sur les maladies des plantes. Thèse requise pour l'obtention du titre Master of Science. Institut agronomique Méditerranéen de Bari. Italie : 94.

Zwart K., (2001), Fate of c and n pools - experience from short and long term compost experiments In applying compost benefits and needs. Seminar proceedings Brussels, 22-23 November 2001. Present in the link: http://ec.europa.eu/environment/waste/pdf_comments/0 40119_proceedings.pdf 